\title{
Assessment of the impact of climate change on surface hydrological processes using SWAT: a case study of Omo-Gibe river basin, Ethiopia
}

\author{
Shiferaw Eromo Chaemiso ${ }^{1} \cdot$ Adane Abebe $^{2} \cdot$ Santosh Murlidhar Pingale $^{2}$
}

Received: 29 October 2016/Accepted: 2 November 2016/Published online: 16 November 2016

(C) Springer International Publishing Switzerland 2016

\begin{abstract}
In the present study, an ArcSWAT model was utilized to simulate the hydrological responses due to land use and climatic changes in the Omo-Gibe river basin, Ethiopia. The performance of the model was evaluated through sensitivity, uncertainty analysis, calibration and validation. The most sensitive parameters were identified which are governing on surface runoff generation processes in the selected basin. The calibration and validation of the model was done using SWAT-2005. Also, the sensitivity and uncertainty analysis was performed using the SUFI-2 and SWAT-CUP algorithm. The model results revealed that a good performance during the calibration $\left(\mathrm{R}^{2}=72.4 \%\right.$, NSE $=62.6 \%$ and $\left.\mathrm{D}=14.37 \%\right)$ and validation $\left(\mathrm{R}^{2}=68.1 \%\right.$, NSE $=68 \%$ and $\left.\mathrm{D}=4.57 \%\right)$. SUFI2 algorithm gave good results in minimizing the differences between observed and simulated flow in the Great Gibe sub-basin. The studies show that there is an overall increasing trend in future annual temperature and significant variation of monthly and seasonal precipitation from the base period 1985-2005. Also, the annual potential evapotranspiration shown increasing trend for future climate change scenarios. Similarly, the surface water decreases in terms of mean monthly discharge in the dry
\end{abstract}

Santosh Murlidhar Pingale

pingalesm@gmail.com; santosh.murlidhar@amu.edu.et

Shiferaw Eromo Chaemiso

shiferomo@gmail.com

1 Department of Hydraulics and Water Resources Engineering, Arba Minch Institute of Technology, Arba Minch University, P.O. Box 21, Arba Minch, Ethiopia

2 Department of Water Resources and Irrigation Engineering, Arba Minch Institute of Technology, Arba Minch University, P.O. Box 21, Arba Minch, Ethiopia season and increases in the wet season. The percentage change in future seasonal and annual hydrological variables was shown increasing trends. Therefore, this study found that SWAT can be effectively used for assessing the water balance components of a river basin in Omo-Gibe basin, Ethiopia.

Keywords SWAT $\cdot$ ArcGIS $\cdot$ Climate change $\cdot$ Water balance $\cdot$ Omo-Gibe basin $\cdot$ Ethiopia

\section{Introduction}

Precipitation is one of the most important hydrological variables of the basin (Sevruk et al. 1998). It greatly influences the amount of water flowing through the water cycle and water availability. Similarly, temperature is another important parameter in assessing the climate change impact on water resources system. According to climate model predictions, using several scenarios of greenhouse gas emissions, global mean temperature probably will increase from 1.1 to $6.4{ }^{\circ} \mathrm{C}$ in the next 100 years (IPCC 2001). This means there will be an increase of extreme weather events as well as change in the precipitation and atmospheric circulation patterns. Shift in precipitation and temperature patterns affects the hydrology process and availability of water resources. Warmer temperature increases the water-holding capacity of the air and thus increase the potential evapotranspiration (PET), reduce soil moisture and decrease groundwater reserves, which ultimately affects the river flows and water availability (IPCC 2001b). Changes in precipitation and evaporation have a direct effect on the groundwater recharge. More intense precipitation and longer drought periods, which are considered to be expected impacts of climate 
changes for most of the land areas of the world, could cause reduced groundwater recharge (IPCC 2001a).

Climate change affects the function and operation of existing water infrastructures including hydropower, structural, drainage and irrigation systems as well as water management practices. The existing land and water resource system of the area is adversely affected by the rapid growth of population, deforestation, surface erosion, and sediment transport and climate change impacts. Climate change increases the vulnerability of poor people, affects their health and livelihoods and undermines growth opportunities crucial for poverty reduction (AfDB 2003). Extreme events due to anthropogenic climate change would cause forced migration and human resettlement resulting in the damage of the social cohesion including the loss of human lives and physical properties. Therefore, it is very important to quantify such impacts in order to identify the variation in decisions and thereby minimize the potential damage magnitude of climate change on a local and regional scale (Chaulagain 2006). This information can point out the sensitive area that might be affected by climate change and help in designing a proper plan to manage water resources in changing climate scenarios (Dincer et al. 2009).

Climate change is one of the crosscutting issues whose impacts need to be considered in any planning. It is considered as one of the risks that might face the future development within the basin, which has to be considered. All these aspects affect livelihoods in the basin but have not received attention in the planning for the future water allocation and design of water infrastructures yet (Kim et al. 2008). It also indicate that developing countries like Ethiopia will be more vulnerable to climate change due to their economic, climatic and geographic settings (IPCC 2007). Also finds the population at risk of increased water stress in Africa. Due to these, the agricultural production from rainfed agriculture could be reduced in some countries that mainly depended on rainfed agriculture. Hence, assessing the impact of climate change on hydrological components like on streamflow, soil moisture, groundwater and other hydrological component, essentially involves projections of climatic variables (e.g. precipitation, temperature, humidity etc.) at a global and local scale were very crucial to investigate the level of climate change impact on water resources (Ghosh and Mujumdar 2009).

Over the last decades, temperature in Ethiopia has increased at about 0.37 and $0.28{ }^{\circ} \mathrm{C}$ per decades (NMA 2007; McSweeney et al. 2008). The increase in minimum temperatures is more pronounced with roughly $0.4{ }^{\circ} \mathrm{C}$ per decade. Precipitation, on the other hand, remained fairly stable over the last 50 years when averaged over the country. However, the spatial and temporal variability of precipitation are high (NMA 2007). Temesgen et al. 2006 studied vulnerability of region to climate change, which indicated that the net effect of sensitivity, exposure, and adaptive capacity are different across the region. Afar, Somali, Oromia, and Tigray are relatively more vulnerable to climate change than the other regions. The vulnerability of Afar and Somali is attributed to their low level of rural service provision and infrastructure development. Tigray and Oromia's vulnerability to climate change can be attributed to the regions higher frequencies of droughts and floods, lower access to technology, fewer institutions, and lack of infrastructure. SNNPR's lower vulnerability is associated with the region's relatively greater access to technology and markets, larger irrigation potential, and higher literacy rate (Temesgen et al. 2006).

The majority of previous studies on the potential impact of climate change on availability of water were limited (i.e. Nile, Awash, Rift Valley river basins). Therefore, this study tried to investigate how changes in terms of temperature and precipitation might translate into changes in streamflow, surface water availability for irrigation and other hydrological parameters using outputs from a regional climate models (RCM). In A1B scenario of RCM output is used to evaluate hydrological impacts on OmoGibe basin water balance. Also, Omo-Gibe river basin area is pastoral and agro-pastoral, the area is highly vulnerable to climate change and adaptation strategy is vital. Hence, new strategies for effective use of the water in the basin particularly in the Omo River basin is needed for water development and management to prevent water scarcities. Therefore, the main objective of the study is to assess the impacts of climate change on hydrological processes such as water balance components of the basin using SWAT model in Omo-Gibe river basin, Ethiopia.

\section{Materials and methods}

\section{Study area}

The Omo-Gibe river basin has an area of $79,000 \mathrm{~km}^{2}$, covering parts of two national regional states, the Southern Nations and Nationality Peoples Region (SNNPR) and Oromia (Fig. 1). It lies between $4^{\circ} 30^{\prime}$ to $9^{\circ} 00^{\prime} \mathrm{N}$ Latitude and $35^{\circ} 00^{\prime}$ to $38^{\circ} \mathrm{E}$ longitude. The total mean annual flow from the river basin is estimated at about 16.6 billion cubic meter (BMC). Gibe River is known as the Omo River in its lower reaches, south-westwards from the confluence with the Gojeb River. The main tributaries of Omo-Gibe River Basin are from north-east Walga, Wabe, Wariness and Derghe and south-west Tunjo (called Gilgel Gibe as station) and Gilgel Gibe Rivers and the west Gojeb River. From the eastern side of the middle and lower Omo-Gibe catchment the Sana, Soke, Wabe, Deme and Zage rivers 


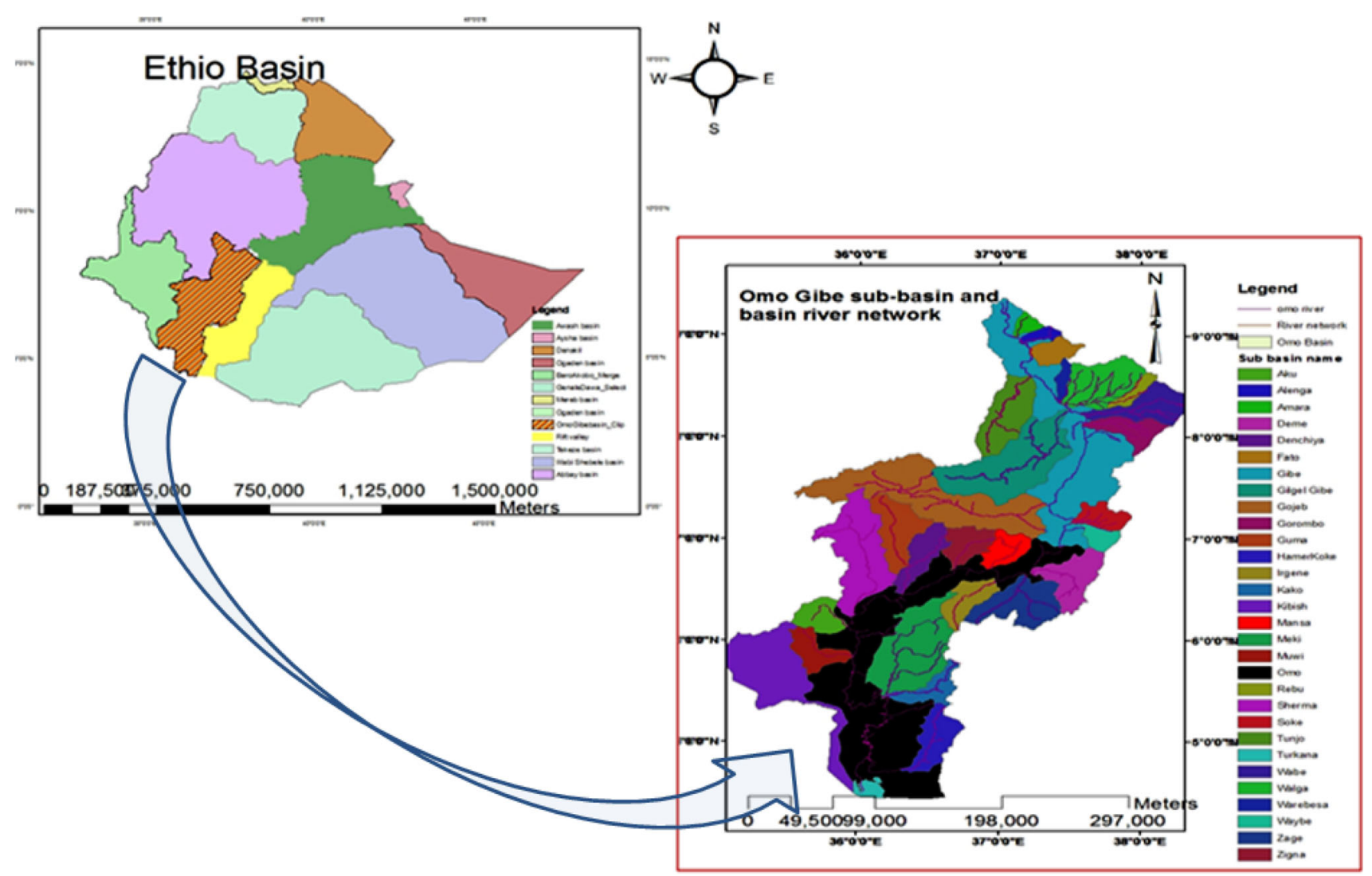

Fig. 1 The index map of the Omo-Gibe river basin, Ethiopia

are the main tributaries. It is an enclosed river basin that flows into the lake Turkana in Kenya, which forms its southern boundary. The western watershed is the range of hills and mountains that separate the Omo-Gibe basin from the Baro-Akobo basin. To the north and north-west the basin is bounded by the Blue Nile basin with small area in the northeast bordering the Awash basin.

Basically, climate of Ethiopia is classified into five climate zones based on the altitude and temperature. Namely, Wurch (cold climate and the altitude is more than $3000 \mathrm{~m}$ ), Dega (temperate like climate of high land and the altitude is between 2500-3000 m), Woina-Dega (warm climate the altitude is between 1500-2500 m), Kola (hot and arid type of climate and the altitude is less than $1500 \mathrm{~m}$ ) and Bereha (hot and hyper arid type of climate) (NMSA 2001). The elevation of the study area is lying between 719 to $3086 \mathrm{~m}$ above the mean sea level (masl). Annual rainfall varies from $400 \mathrm{~mm}$ in the extreme south low land to $1900 \mathrm{~mm}$ in the high land with the average being $1140 \mathrm{~mm}$. The mean annual temperature in the basin varies from less than $17{ }^{\circ} \mathrm{C}$ in the west highlands to cover $29^{\circ} \mathrm{C}$ in the south low lands (MoWR 1996). The high lands areas have elevations of 3625 masl on mount Ghuge while the low land areas fall in the altitudes of up to 235 masl. Steep slopes with dissected hills characterize the highlands while the low lands are characterized by relatively gentle and undulating slopes. The soils in the basin is highland soils and low land soils. High land soils are the vast and majority of the parent materials in the high lands are igneous rocks which under the influence of a pluvial regime and relatively warm temperatures have weathered to form deep well drained clay soils with moderate natural fertility over almost all the high land areas. Low land soils: soil derived primarily from siliceous basement rocks or alluvial soils reworked from soils derived from these rocks are generally coarse grained and have a low nutrients status. Other alluvial soils can have moderate to high fertility. However in the low lands, cultivation is generally excluded by climate (MoWR 1996).

\section{Data collection and database preparation}

The meteorological (temperature, precipitation, relative humidity, sunshine hour and wind speed), hydrological, land use, and soil data was collected from Ministry of Water Resource and Energy office (MoWE) and National Meteorological Agency (NMA). Daily rainfall data of 20 years were collected from more than 20 gauging stations in the Omo-Gibe River basin (Fig. 2). The 19 years (1986-2005) of daily discharge data was used for this study. The digital elevation model (DEM) was obtained 


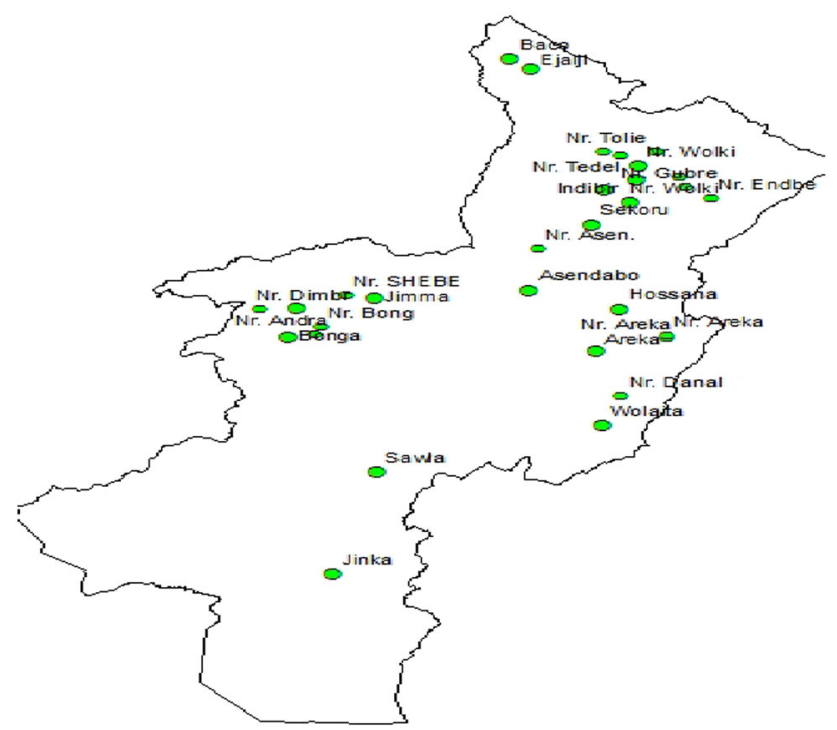

Fig. 2 Rainfall gauging stations located in Omo-Gibe river basin

from the NASA Shuttle Radar Topographic Mission (SRTM) with a resolution of $90 \mathrm{~m} \times 90 \mathrm{~m}$ (Fig. 3a). Slope was generated from DEM using ArcGIS 9.3 (Fig. 3b). It is used to analyze the drainage pattern of the watershed, slopes, stream lengths, and widths of channel within the watershed. The soil and land use data was obtained from MoWE using GIS (Fig. 4). The areal coverage of the LULC and slope of the basin are presented in Tables 1 and 2. The raw data was processed for consistencies and homogeneities, filling of missed data, and quality check.
The inconsistency of a record was checked by double mass curve technique (Subramanya 1998).

The RCM data has been obtained from the International Water Management Institute (IWMI) for the different time periods (2030s and 2090s) of A1B scenario. The bias correction was applied to the RCM data of future precipitation and temperature. The climate data (GCM) are downscaled into fine spatial resolution RCM data of A1B scenario. The nonlinear correction for each daily precipitation $\mathrm{P}$ and a linear bias correction for temperature $\mathrm{T}$ was applied and transformed to a corrected $\mathrm{p}^{*}$ and $\mathrm{T}^{*}$, respectively, using:

$\mathrm{p}^{*}=\mathrm{aP}^{\mathrm{b}}$ and $\mathrm{T}^{*}=\mathrm{a} * \mathrm{~T}+\mathrm{b}$.

The coefficient $\mathrm{a}$ and $\mathrm{b}$ are determined iteratively.

\section{Configuration of hydrological model using SWAT}

SWAT (Soil and Water Analysis Tool) model was developed by USDA in 1995. It is semi-distributed physically based hydrological model operating on a daily time step. SWAT has been successfully applied numerous times for long-term continuous simulations of flow, soil erosion, and sediment and nutrient transport in watersheds of different sizes, and having different hydrologic, geologic, and climatic conditions. The model has been useful to study impacts of certain climate changes on long term water yields, and the impacts of certain management scenarios on long term sediment and nutrient loads. The SWAT model embedded in ArcGIS interface and works on the principle

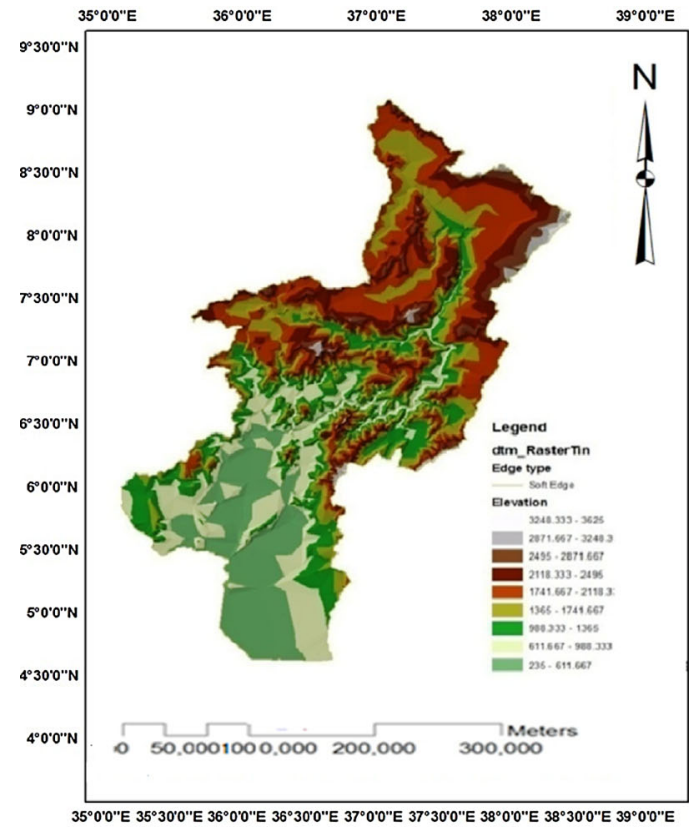

(a)

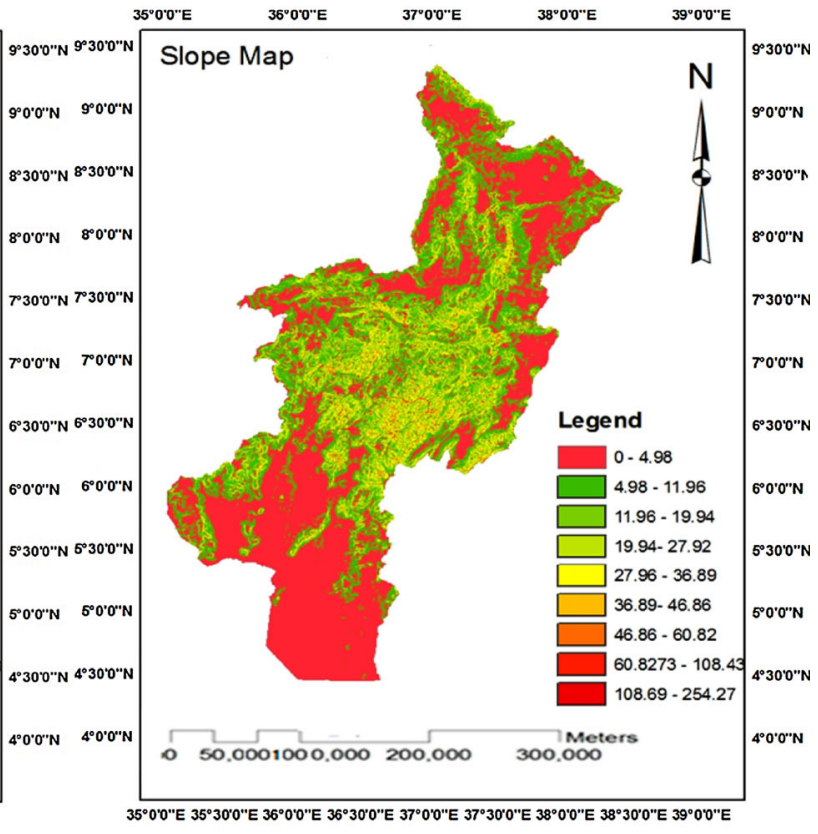

(b)

Fig. 3 a DEM and b slope (\%) of the study area 


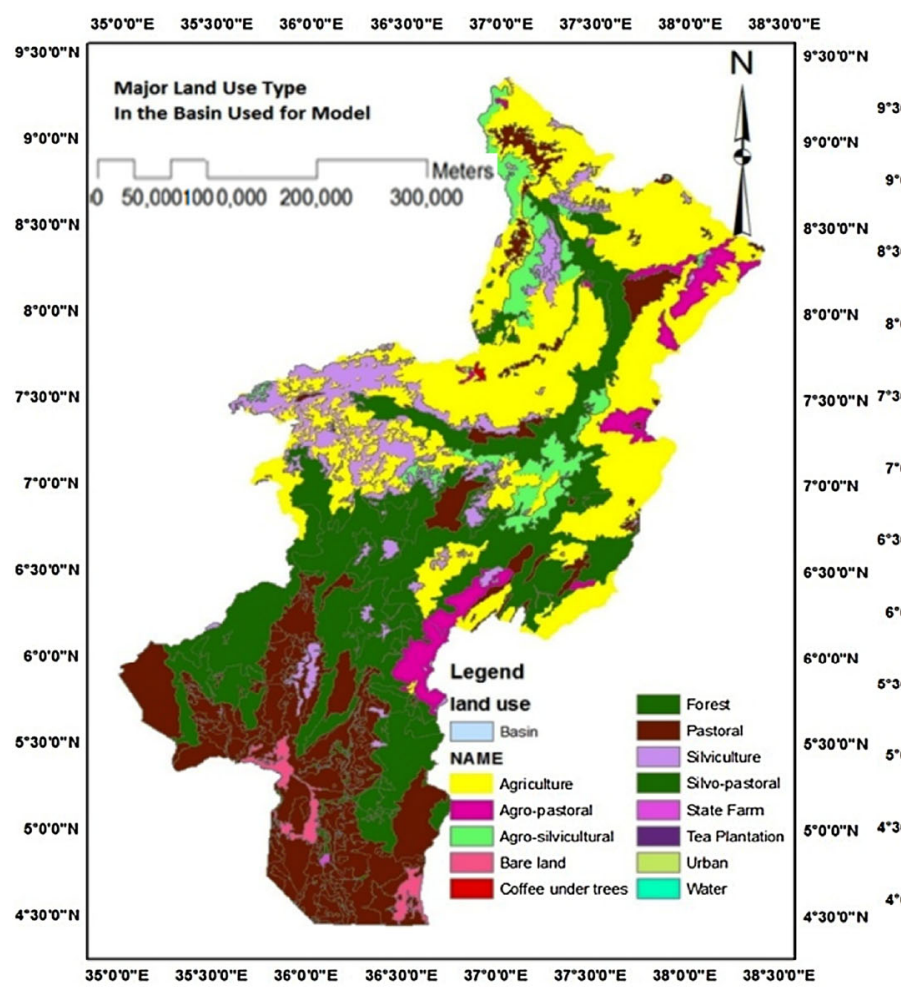

(a)

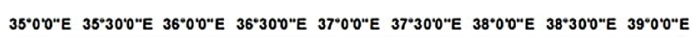

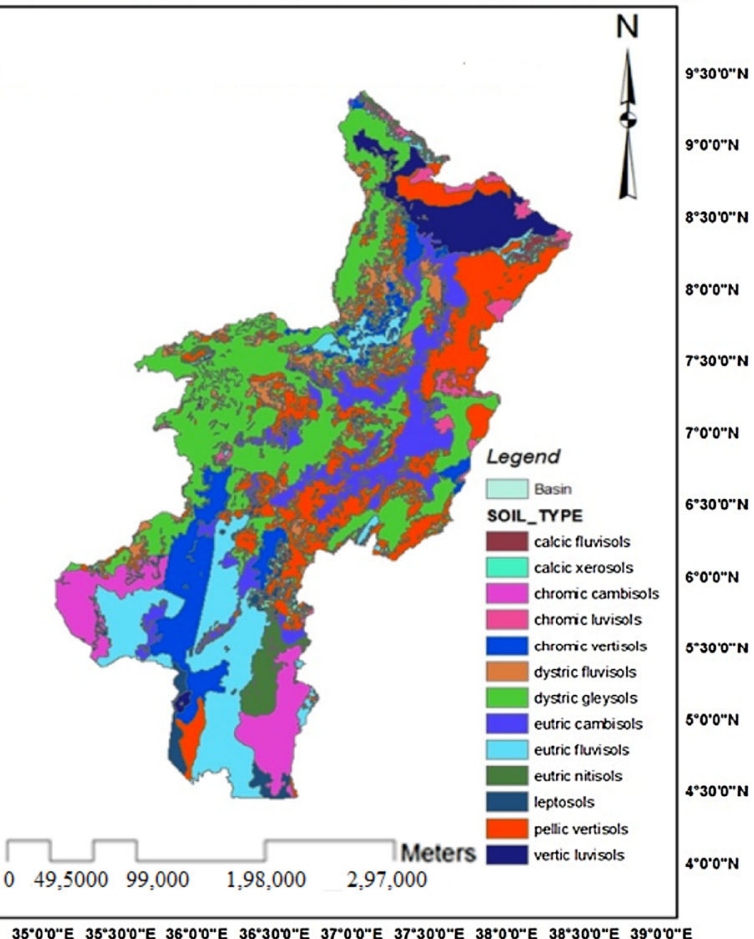

(b)

Fig. 4 a Delineated LULC and b soil map of the study area

Table 1 The statistics of land use land cover

\begin{tabular}{lllrc}
\hline No. & Land use type & SWAT code & Area (ha) & \% Coverage \\
\hline 1 & Wood land & AGRR & $3,179,060$ & 44.83 \\
2 & Cultivation & AGRC & 300,224 & 4.23 \\
3 & Natural forest & PAST & $3,148,696$ & 44.4 \\
4 & Shrubs land & WATR & 840 & 0.81 \\
5 & Grass land & SPAS & 320,224 & 4.52 \\
6 & Afro-alpine & FRSE & 31,412 & 0.44 \\
7 & Plantation & COFF & 4920 & 0.65 \\
8 & Water & URBN & 1572 & 0.12 \\
\hline
\end{tabular}

Table 2 Slope class of Omo-Gibe Basin

\begin{tabular}{llcll}
\hline No. & Classes slope & Range in $\%$ & Area (ha) & $\%$ of coverage \\
\hline 1 & 1 & $0-5$ & $3,082,284$ & 43.46 \\
2 & 2 & $5-15$ & $2,281,008$ & 32.16 \\
3 & 3 & $15-999$ & $1,654,228$ & 23.33 \\
\hline
\end{tabular}

of dividing the watershed into a number of homogenous sub-basins that is called hydrologic response units (HRUs) which have unique soil, slope and land use properties (Neitsch et al. 2004; Arnold and Fohrer 2005). Hydrological cycle as simulated by SWAT is based on the water balance equation
$S_{w t}=S_{w o} \sum_{i=1}^{t}\left(R_{\text {day }}-Q_{\text {surf }}-E_{a}-S_{\text {seep }}-Q_{g w}\right)$,

where, Swt is the soil water content (mm), Swo is the initial soil water content $(\mathrm{mm}), \mathrm{Q}_{\text {surf }}$ is the surface runoff $(\mathrm{mm})$, $R_{\text {day }}$ is the amount of precipitation (mm), Ea is the Amount of evapotranspiration $(\mathrm{mm}), \mathrm{W}_{\text {seep }}$ is the soil infiltration $\mathrm{i}$ $(\mathrm{mm})$, and $\mathrm{Q}_{\mathrm{gw}}$ is the return flow ( $\mathrm{mm}$ ).

In this study, the SCS curve number method was used to estimate surface runoff. FAO Penman-Monteith method was adopted to calculate the daily potential evaporation (Allen et al. 1998).

\section{Calibration and validation}

The stations from a period of 1985-1998 has been used for model calibration and 1999-2005 used for model validation. After calibrating the models at the main gauging station, comparison and selection of the best model were made. The model performance was evaluated at both catchments, then simulation of the flow was made on Gilgel Gibe three dam sites for optimizing the impact of climate change on extreme seasonal flows. The future climate change impact was assessed on the availability of water balance in the catchments. The detailed methodology adopted in the present study has been presented in the Fig. 5. 
Fig. 5 Flow chart for the general frame work of the study

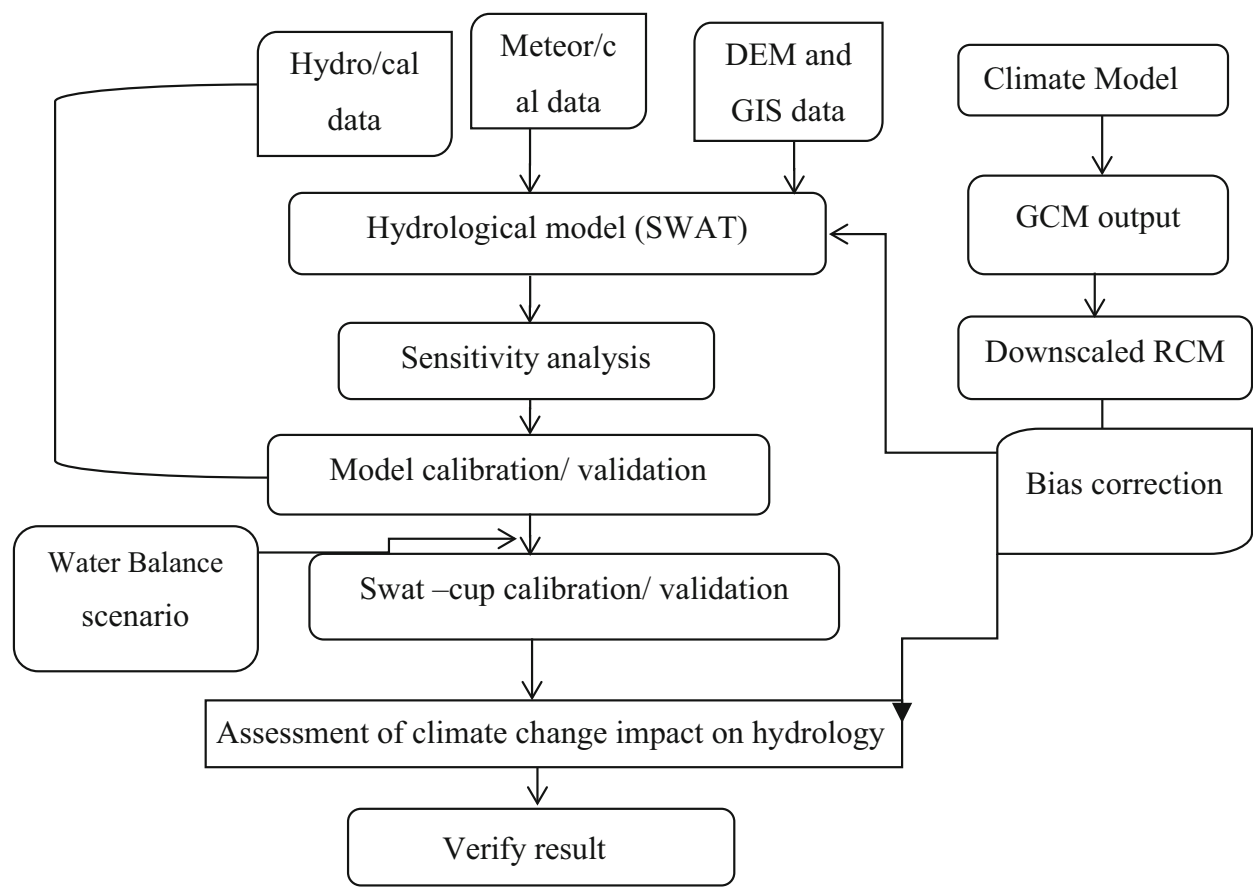

In this study, the SWAT-CUP was used to perform uncertainty and sensitivity analysis during calibration and validation of the SWAT. The SUFI-2 algorithm was used in SWAT calibration and validation which represents the uncertainties of all sources (i.e. input, model and output) (Yang et al. 2008). It can perform parameter sensitivity analysis to identify those parameters that contributed most to the output variance due to input. A comprehensive description on the SUFI-2 can be found in (Abbaspour et al. 1997).

The model performance in simulating observed discharge was evaluated during calibration and validation by the three performance indicators: Nash and Sutcliffe efficiency (NSE) (Nash and Sutcliffe 1970), coefficient of determination $\left(\mathrm{R}^{2}\right)$ and Percent difference/Relative Volume Error (D). Their formulations are given as follows:

$N S E=1-\frac{\sum_{i=1}^{n}\left[Q_{o}-Q_{s}\right]^{2}}{\sum_{i=1}^{n}\left[Q_{o}-\overline{Q_{o}}\right]^{2}}$

$R^{2}=\frac{\left[\sum_{i=1}^{n}\left(Q_{s}-\overline{Q_{s}}\right)\left(Q_{o}-\overline{Q_{0}}\right)\right]^{2}}{\left[\sum_{i=1}^{n}\left(Q_{s}-\overline{Q_{s}}\right)\right]^{2}\left[\sum_{i=1}^{n}\left(Q_{o}-\overline{Q_{o}}\right)\right]^{2}}$

$D=100 \% \times\left[\frac{\sum_{i=1}^{n} Q_{o}-\sum_{i=1}^{n} Q_{s}}{\sum_{i=1}^{n} Q_{o}}\right]$,

where, $\mathrm{Q}_{o}$ is the observed flow, $\mathrm{Q}_{\mathrm{s}}$ is the simulated flow, $\overline{Q_{O}}$ is the average of observed flow and $\overline{Q_{s}}$ is the average of simulated flow.

\section{Results and discussion}

\section{Sensitivity analysis}

According to Lenhart et al. (2002), the sensitivity analysis has been carried out for 27 parameters and the most sensitive parameters were identified (Table 3). The results of the sensitivity analysis showed that $\mathrm{CN}$ is the top rank for flow yield, followed by soil evaporation compensation factor, base flow alpha factor and so on (Table 3).

\section{Uncertainty analysis using SWAT_CUP}

There are various sources of uncertainties which is related to data, model assumptions and GCM output. After finding the sensitive parameters on streamflow simulation (Table 4), the SUFI-2 algorithm was used in SWAT-CUP to calculate the calibration and validation parameters. Then, the calibration periods were defined from 1992 to 1996 and the validation period from 1998 to 2000 . SUFI-2 algorithms gave good results in minimizing the differences between observed and simulated flow in the Great Gibe sub-basin. The p-factor and r-factor was found more than 60\% (Table 5; Figs. 6, 7, 8, 9). According to Bosch et al. (2004) found that SWAT stream flow estimates for small watershed were more accurate using high resolution topographic, land use, and soil data versus low resolution data obtained from basins. Cotter et al. (2003) report that DEM resolution was the most critical input for a SWAT simulation of DEM, land use, and soil resolution to obtain accurate flow, sediment, nitrate. 
Table 3 Sensitivity ranking of parameters towards water flow

\begin{tabular}{|c|c|c|c|c|}
\hline Rank & Parameter symbol & Description & Mean relative & Sensitivity \\
\hline 1 & $\mathrm{Cn} 2$ & Initial SCS runoff curve number & $2.89 \mathrm{E}-01$ & High \\
\hline 2 & Esco & Soil evaporation compensation factor & $2.51 \mathrm{E}-01$ & High \\
\hline 3 & Alpha_Bf & Base flow alpha factor & $2.26 \mathrm{E}-01$ & High \\
\hline 4 & Revapmn & Threshold depth of water in the shallow aquifer for re-evaporation to occur & $1.60 \mathrm{E}-01$ & Medium \\
\hline 5 & Ch_K2 & Effective hydraulic conductivity in the main channel alluvium & $1.35 \mathrm{E}-01$ & Medium \\
\hline 6 & Gwqmn & Threshold depth of water in the shallow aquifer required for return flow to occur & $1.01 \mathrm{E}-01$ & Medium \\
\hline 7 & Sol_Z & Depth from soil surface to bottom of layer & $9.62 \mathrm{E}-02$ & Small \\
\hline 8 & Sol_Awc & Available soil water capacity $(\mathrm{m} / \mathrm{m})$ & $9.33 \mathrm{E}-02$ & Small \\
\hline
\end{tabular}

Table 4 Maximum and minimum boundaries of the parameters and fitted values after calibration

Table 5 SUFI-2 algorithms iteration

Fig. 6 Calibration result of average monthly simulated and measured flow at the outlet of the sub basin 5, where Great Gibe gauging station is located

\begin{tabular}{llllcc}
\hline No. & Parameter name SUFI-2 & Lower bound & Upper bound & \multicolumn{2}{c}{ Final fitted value } \\
\cline { 5 - 6 } & & & Daily & Monthly \\
\hline 1 & r_CN2.mgt & $-25 \%$ & $25 \%$ & 0.85 & 0.75 \\
2 & r_SOL_AWC.sol & $-25 \%$ & $25 \%$ & 0.02 & 0.021 \\
3 & r_CH_K.rte & 0 & 150 & 11.8 & 6.20 \\
4 & v_ALPHA_BF.gw & 0 & 1 & 0.068 & 0.044 \\
5 & v_GWQMN.gw & 0 & 5000 & 37.84 & 35.65 \\
6 & v_Esco.hru & 0 & 1 & 0.01 & 0.01 \\
7 & V_REVAPMN.gw & 0 & 500 & 0.04 & 0.012 \\
\hline
\end{tabular}

$\mathrm{r}_{-}$means relative change $(\%)$ and $\mathrm{v}_{-}$means value change

\begin{tabular}{llllll}
\hline Index & Calibration & & Validation & \\
\cline { 2 - 3 } & Nash-Sutcliff efficiency & $\mathrm{R}^{2}$ & & Nash-Sutcliff efficiency & $\mathrm{R}^{2}$ \\
\hline Monthly & 0.64 & 0.69 & & 0.71 & 0.72 \\
Daily & 0.642 & 0.66 & & 0.6 & 0.68 \\
\hline
\end{tabular}

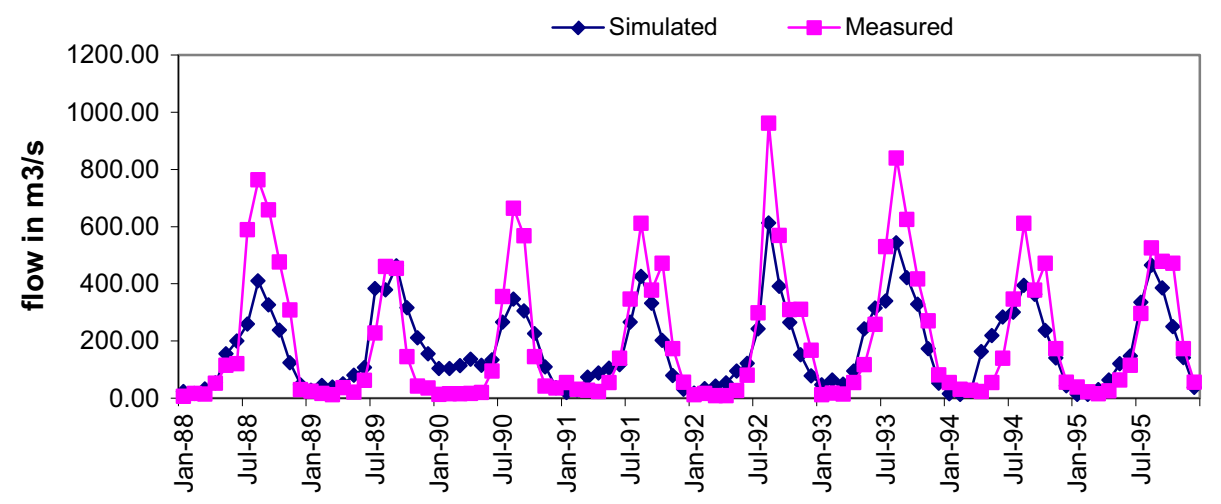

\section{Calibration and validation at Great Gibe, Abelti and Gojeb sub-watershed}

Calibration and validation processes were performed using the Parasol and manual methods using SWAT2005, and the SUFI-2 methods for SWAT-CUP. The calibration was done using historical records of 10 years (1985-1995) of Great Gibe gauging station. The curve number (CN), Soil evaporation compensation factor, Base flow alpha factor (ALPHA_BF), Threshold depth of water in the shallow aquifer for re-evaporation to occur (REVAPMN), Effective and hydraulic conductivity in the 
Fig. 7 Monthly calibration (a) and validation (b) results showing the $95 \%$ prediction uncertainty intervals along with the measured discharge at Great Gibe near to Abelti Gauging station

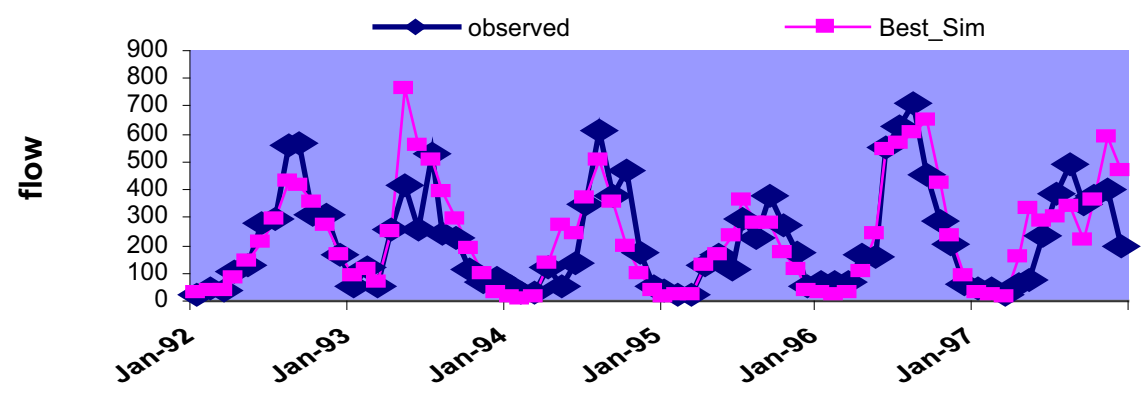

(a)

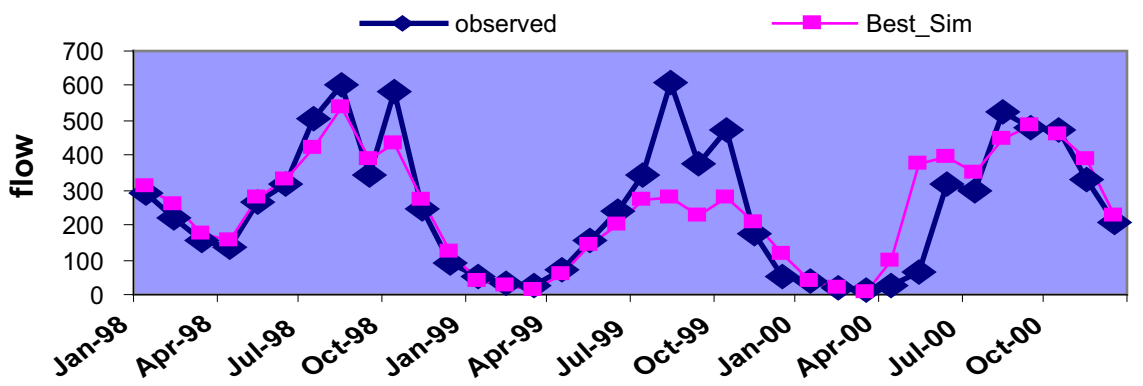

(b)

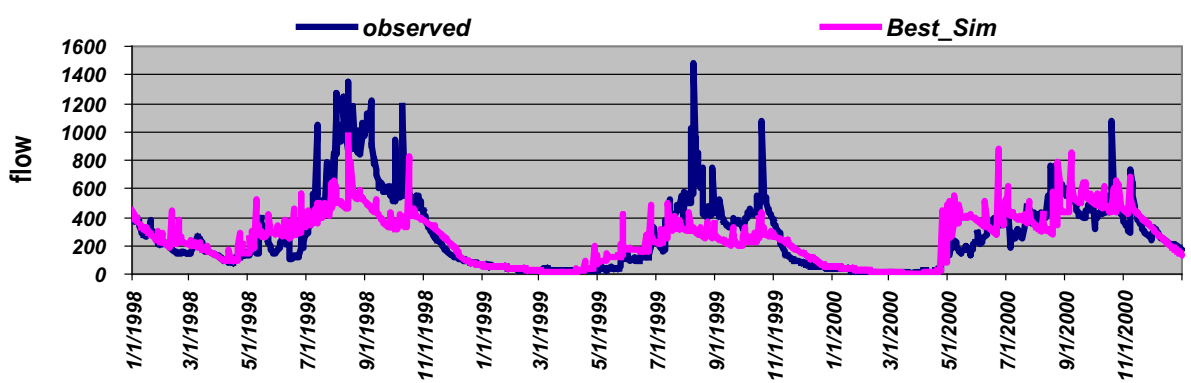

(a)

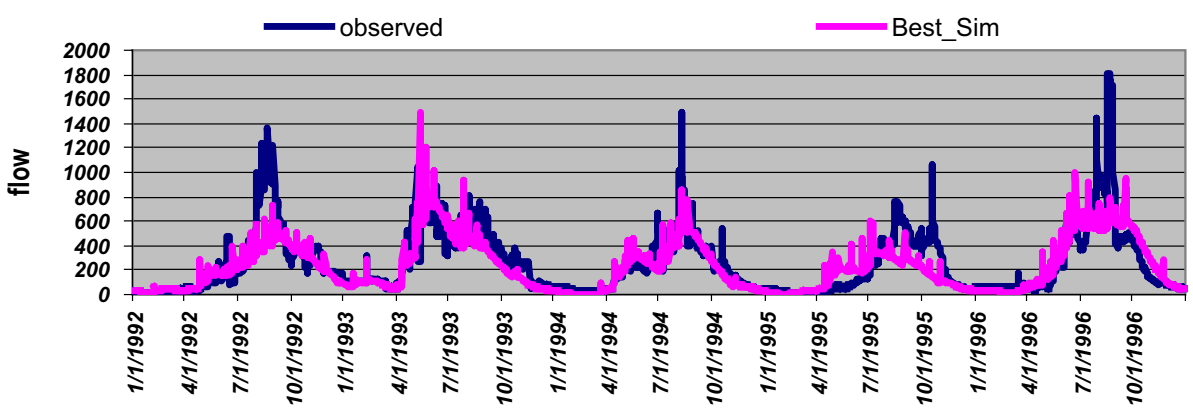

(b) main channel alluvium, Threshold depth of water in the shallow aquifer required for return flow to occur (GWQMIN) parameters were used to carry out the water balance part of the calibration. The first eight parameters were considered according to their relative sensitivity for temporal flow calibration (Table 6). Each time the temporal calibration is finalized, the water balance was also checked since the adjustment of the base flow parameters can also affect the surface runoff volume. The performance of the calibrated model was carried out using statistical indicators [i.e. Nash-Sutcliffe coefficient (NSE), Coefficient of Determination $\left(\mathrm{R}^{2}\right)$ ]. In the validation, data for a period of three years from the same station of the years 1996-2000 was used. 
Fig. 9 Correlation graph between measured and validated model results

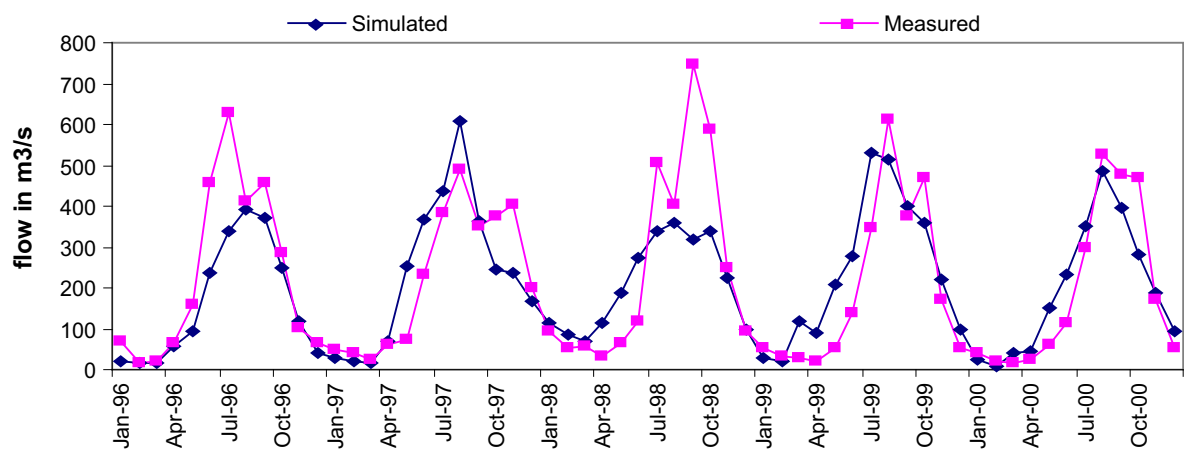

As discussed in data analysis section, the flow was calibrated automatically by the model using the observed areal precipitation, areal evapotranspiration and observed flow at abelti gauging station. The calibration was performed for 8 years period from January 1, 1988 to December 31, 1995. The performance of the model for both simulated and measured flow has been presented in Table 7 . The $\mathrm{R}^{2}$ was found to be 0.724 , NS $=0.626$, and $\mathrm{D}=14.34$ which shows the simulation's very good correlation with the gauged flow (Figs. 6, 7, 8). DEM resolution affects delineation of the watershed and stream network. A decrease in spatial resolution results in a decrease in the volume of simulated stream flow. The DEM $90 \mathrm{~m} \times 90 \mathrm{~m}$ required to achieve less than $14.34 \%$ error at calibration and $4.57 \%$ in validation error of flow simulation in this basin. The validation was performed for 5 years period from January 1, 1996 to December 31, 2000. The results indicates that the simulated flow has very good correlation with the gauged flow $\left(\mathrm{R}^{2}=0.681\right.$ and NSE $=0.68$ ) (Table 7; Fig. 9). In addition, regression plots also confirms measured and simulated monthly streamflow in good agreement (Fig. 10). Similar to the Great Gibe and Abelti sub watershed, the model was calibrated and validated (January 1, 1996 to December 31, 2000) for Gojeb sub watershed (Table 7). The performance of the model was found very good for simulated flows $\left(\mathrm{R}^{2}=0.74\right.$ and $\left.\mathrm{NSE}=0.714\right)$. Also regression plot confirms measured versus simulated monthly streamflow (Fig. 11).

Table 7 Performance of calibration and validation

\begin{tabular}{llllllll}
\hline Station & \multicolumn{2}{l}{ Calibration } & & \multicolumn{3}{l}{ Validation } \\
\cline { 2 - 4 } & NSE & $\mathrm{R}^{2}$ & $\mathrm{D}$ & & NSE & $\mathrm{R}^{2}$ & $\mathrm{D}$ \\
\hline Abilate & 0.626 & 0.724 & 14.34 & & 0.676 & 0.681 & 4.57 \\
Gojeb & 0.644 & 0.705 & -1.87 & & 0.714 & 0.732 & 0.51 \\
\hline
\end{tabular}

\section{Water balance components on average annual basis}

SWAT model can be effectively used for assessing the water balance components of a river basin. Water balance components before and after calibration such as surface runoff, lateral flow, base flow and evapotranspiration show in Fig. 12 and Table 8. The prediction of basin water balance is based on the simulation result from 1985 to 2005. The estimated annual precipitation falling on the basin is $1380.8 \mathrm{~mm}$ and the evaporation loss from the basin is about 645 and $1407.5 \mathrm{~mm}, 1485.9,1568 \mathrm{~mm}$ annual precipitation and $659.9,719.9,770.9 \mathrm{~mm}$ the evaporation loss for the $2030 \mathrm{~s}$ and $2090 \mathrm{~s}$, respectively.

\section{Assessment of climate change and water balance in Gibe III}

The results shows that increasing trend in future average maximum and minimum temperature for most of the subbasins (Fig. 13a), but in the case of the precipitation, the future condition exhibits a fluctuating trend i.e. in some of the sub-

Table 6 The percentage change in annual hydrological variables of future periods with respect to the base period

\begin{tabular}{lcccccc}
\hline Time & \multicolumn{2}{c}{ GCM output date corrected A1B scenario } & & \multicolumn{2}{c}{ Percentage of change } \\
\cline { 2 - 3 } Hydrological component & Baseline 2000s & $2030 \mathrm{~s}$ & $2090 \mathrm{~s}$ & & $\% \Delta 2030$ & $\% \Delta 2090$ \\
\hline Precipitation (mm) & 1407.5 & 1485.9 & 1568 & & 5.6 & 11.4 \\
Evapotranspiration (mm) & 659.9 & 719.9 & 770.9 & & 9.1 & 16.8 \\
Surface runoff (mm) & 66.86 & 71.72 & 83.6 & & 7.3 & 25.0 \\
Ground water flow (mm) & 465.41 & 547.62 & 553.3 & & 17.7 & 18.9 \\
Lateral flow (mm) & 113.9 & 114.35 & 121.09 & & 0.4 & 6.3 \\
Percolation below root zone (mm) & 506.25 & 582.33 & 591.78 & & 15.0 & 16.9 \\
Transmission losses (mm) & 7.92 & 8.46 & 8.84 & & 6.8 & 11.6 \\
Total water yield & 696.83 & 725.24 & 749.15 & & 4.1 & 7.5
\end{tabular}


Fig. 10 Regression plots of measured versus simulated monthly streamflow relative to lines for the a Calibration period (1988-1995), and b validation period (1996-2000)
Fig. 11 Regression plots of measured versus simulated monthly streamflow relative to $1: 1$ lines for the a calibration period (1988-1995), and b validation period (1996-2000)

\section{(a) Calibration period}
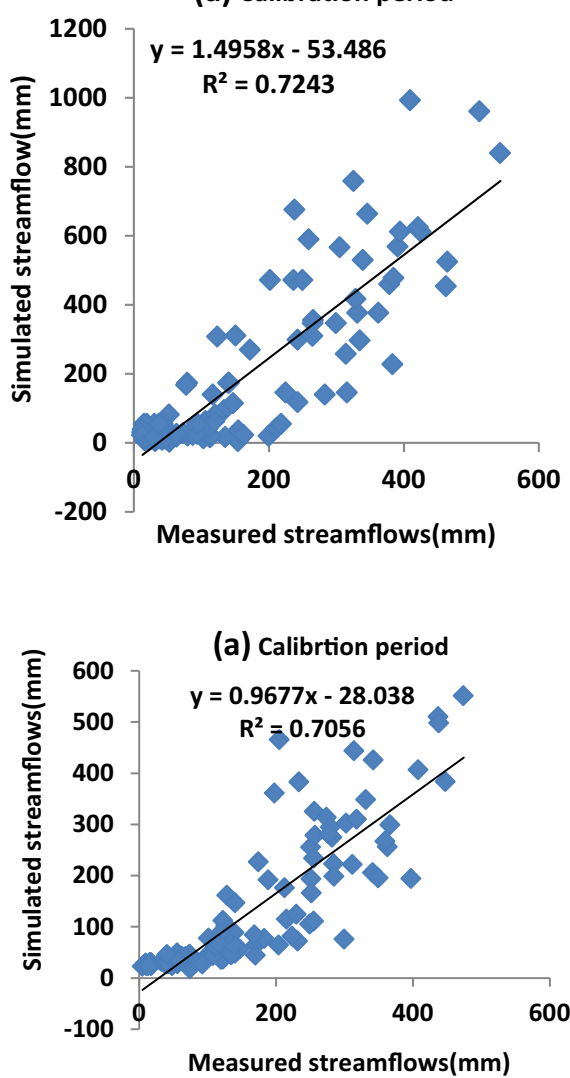

(b) Validation period
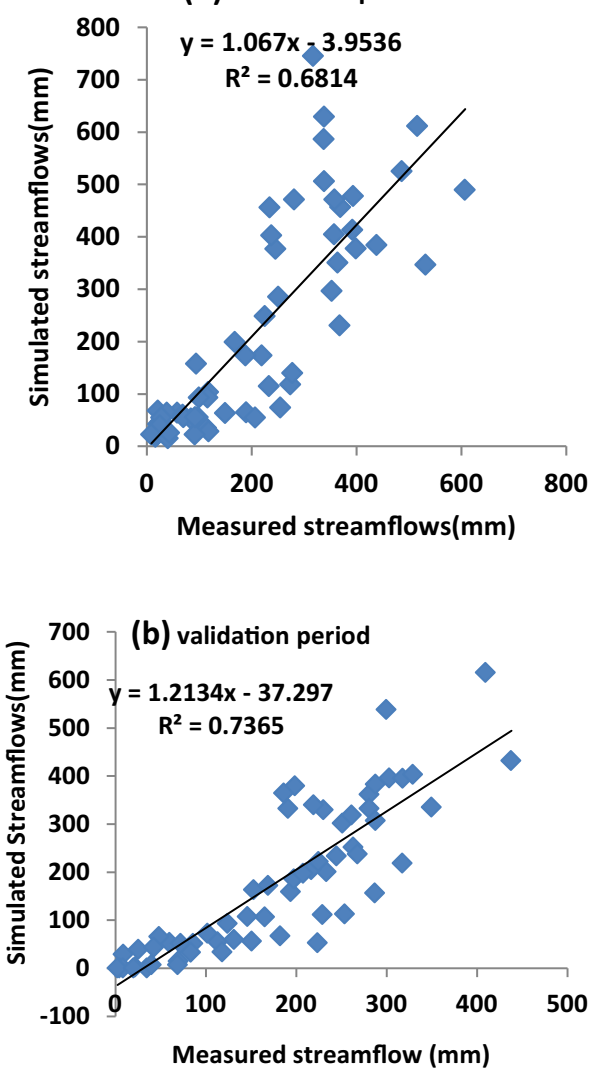

Fig. 12 Water balance in the basin

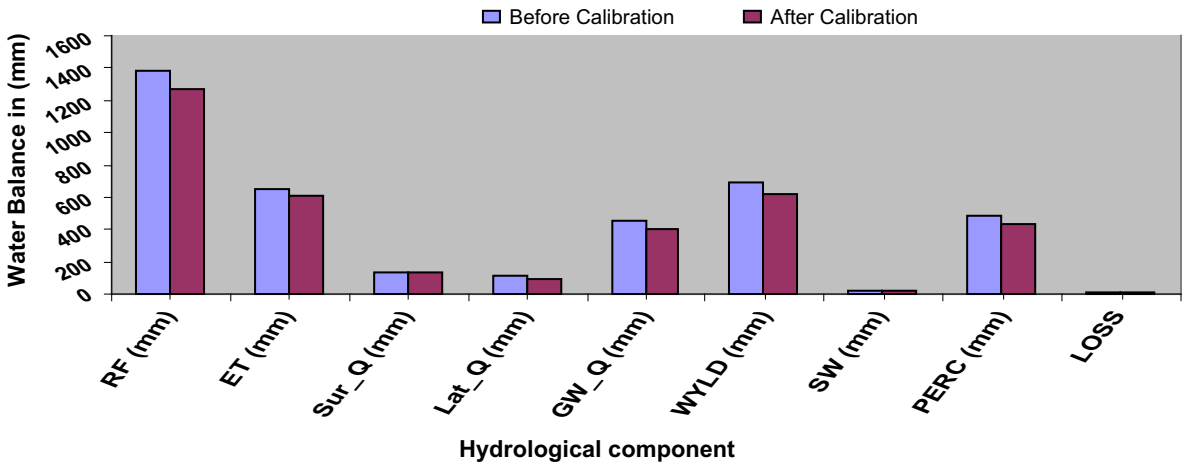

basin increasing and in other decreasing trend. This may attributed to complex nature of precipitation processes and its distribution in space and time. Figure $13 \mathrm{~d}$ shows the trend change of precipitation in 2030-2040 for sub-basin decreasing trend in Belg season and Bega and increasing Kiremt season, but for long term 2091-2100 increasing in Bega and Kiremt decreasing in Belg season. The average annual evaporation for Gibe III shows an increasing trend from short term (2030-2040) to long term (2091-2100) in A1B scenario (Fig. 14a). The results of the analysis of the mean seasonal temperature record clearly showed that all the stations had positive trends in Bega, Belg and Kiremt seasons. The temperature is showing an increasing trend in Gibe III Fig. 14b.
Impact of climate change on water availability was assessed based on climate change scenarios for the watershed. The future projected precipitation and temperatures were downscaled using A1B scenario for the two future climate periods (2030s and 2090s). The SWAT simulation for the 1985-2005 period was used as a baseline period against which the climate impact was assessed. The daily precipitation and minimum and maximum temperature of the future two periods: 2030-2040 and 2090-2100 were directly used as input for SWAT. Other climate variables as wind speed, solar radiation, and relative humidity were assumed to be constant throughout the future simulation periods based on this scenario. In Fig. $15 \mathrm{~b}$ and Table 9 
Table 8 Water balance components and model result before and after calibration

\begin{tabular}{|c|c|c|c|c|c|c|c|c|c|}
\hline Period & $\mathrm{RF}(\mathrm{mm})$ & $\mathrm{ET}(\mathrm{mm})$ & Sur_Q (mm) & Lat_Q (mm) & GW_Q (mm) & WYLD (mm) & $\mathrm{SW}(\mathrm{mm})$ & PERC (mm) & Loss \\
\hline Before & 1380.8 & 645.8 & 136.30 & 108.99 & 456.25 & 692.47 & 16.42 & 489.19 & 9.07 \\
\hline After & 1270.2 & 609.7 & 132.82 & 93.72 & 404.43 & 622.76 & 22.10 & 433.81 & 8.21 \\
\hline
\end{tabular}

$E T$ evapotranspiration, $S U R Q$ surface runoff, $L A T Q$ lateral flow into stream, $G W \_Q$ groundwater contribution to stream flow, WYLD SURQ + LATQ + GW_Q-LOSSES, SW soil water, PERC percolation below root zone (groundwater recharge)
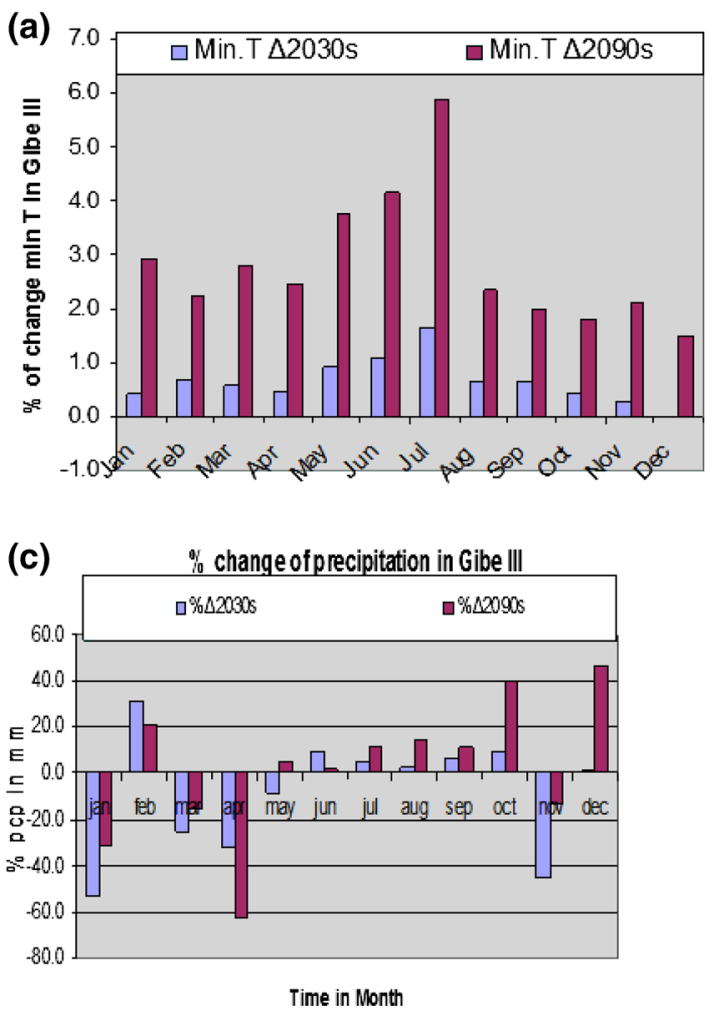
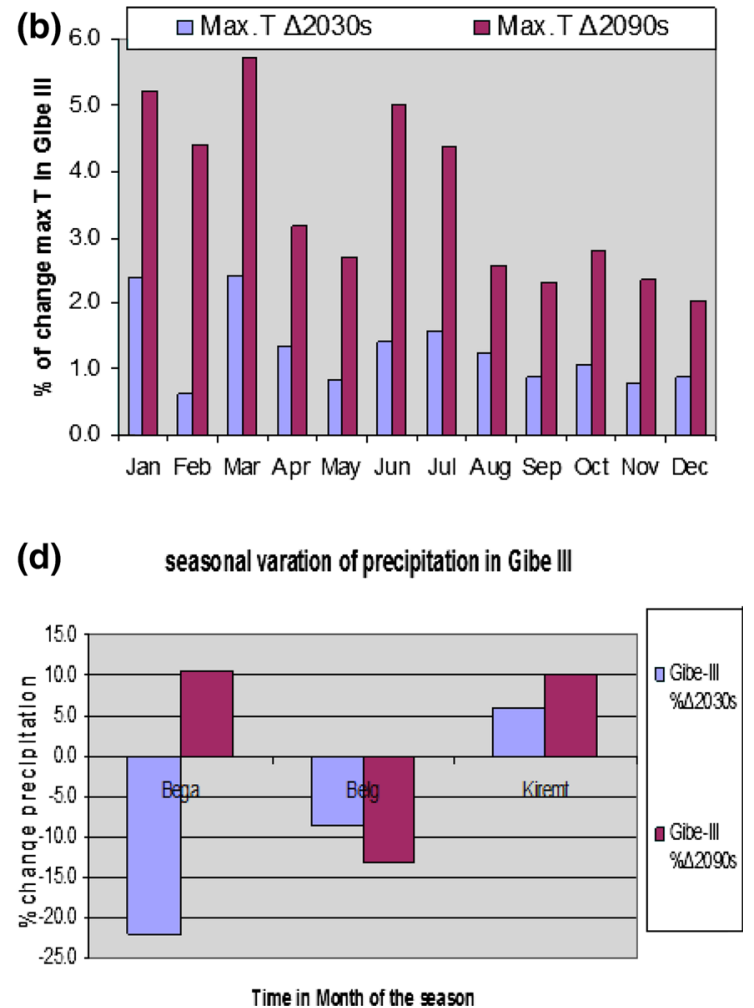

Fig. 13 a Minimum and $\mathbf{b}$ maximum temperature, \% change; $\mathbf{c}$ monthly percentage change in precipitation Gibe III and $\mathbf{d}$ seasonal variation of precipitation for Gibe III

above the percentage change in seasonal and annual hydrological variables of future periods was showing that increasing trends.

\section{Impact of climate change on future surface water availability}

Changes in climate (precipitation and temperature) can have a significant effect on the quality and balance of surface water. After calibration and validating the hydrological model with the historical records and bias correction of the meteorological variables of downscaled GCM output, the next step is the simulation of river flows in the watershed. Also, subsequently the hydrological model was used to identify possible trend in the simulated river flow. Impact of climate change on water availability was assessed based on climate change scenarios using RCM model output which was downscaled from GCM model for the watershed. Based on this, the hydrological impact of the Omo-Gibe basin was analyzed using the SWAT model for the future A1B scenario (2030s and 2090s).

The SWAT simulation for the 1985-2005 period was used as a baseline period. Even if, it is definite that in the future land use changes will also take place. This was also assumed to be constant in this study to investigate the impact with respect to the change in the climate variables keeping all other factors constant. Therefore, Table 9 and Fig. 16 show that percentage change of precipitation and evaporation for future long time mean annual change increasing trend from -2.58 to $2.49 \%$ precipitation 2030 s to 2090 s and $5.52-12.35 \%$ evaporation 2030 s-2090s. The 
Fig. 14 a Monthly percentage change evaporation in Gibe III and $\mathbf{b}$ seasonal temperature

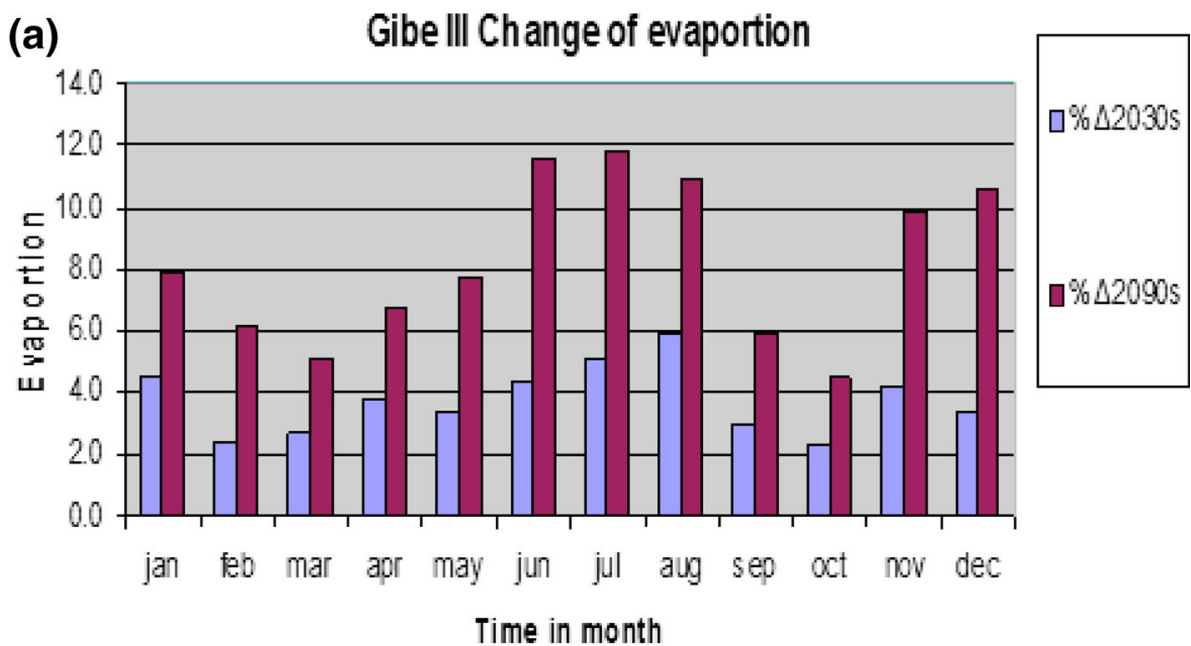

(b)

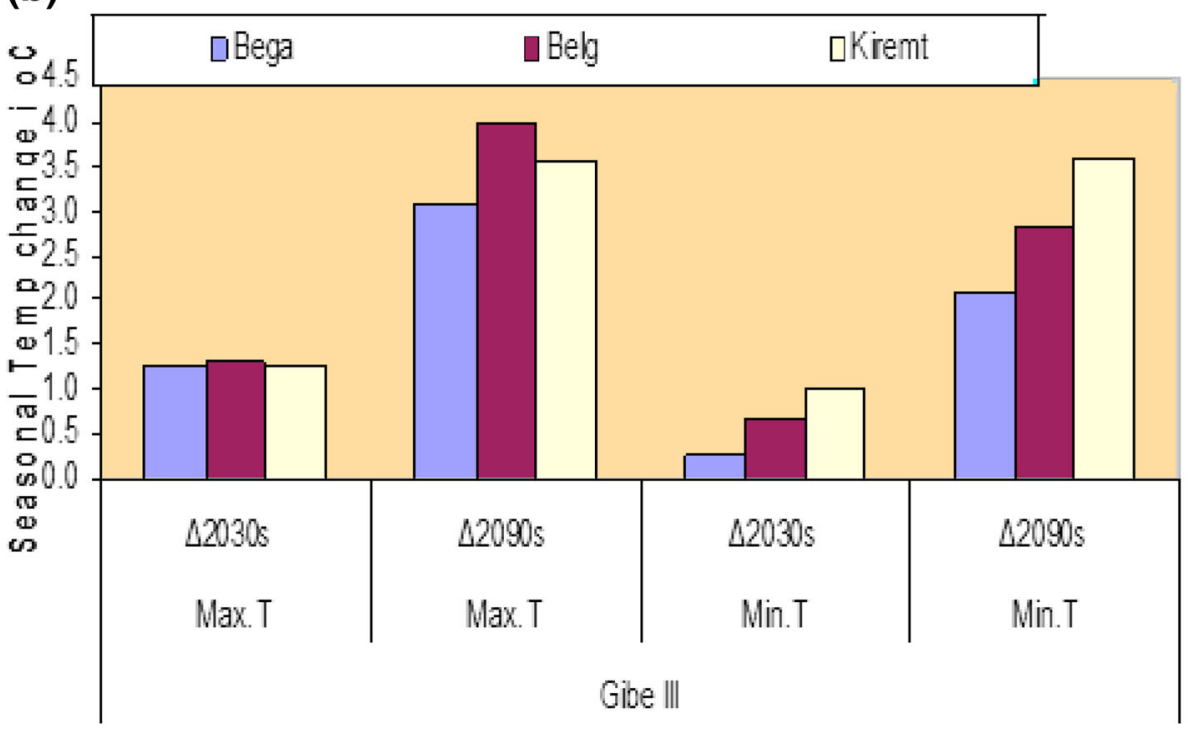

Time in year future precipitation and evaporation shown both decrease for January, April, and precipitation decrease in Mar and Nov (Fig. 16). The other months showed the increase trend on the whole. This is mainly because of the dominant impact of the average seasonal precipitation. In general, the mean seasonal and annual change of soil moisture varies with precipitation and evapotranspiration. Additionally, the future soil moisture will also vary with changing water yields, surface runoff and lateral runoff which are directly or in directly affected by climate change. These changes of the climate variables were applied to SWAT hydrological model to simulate future water availability. The results indicate annual potential evapotranspiration has increasing trend for both future climate periods (Fig. 17).

\section{Conclusions}

In the present study, the physically based semi-distributed SWAT model was used to assess the impact of climate change on hydrological processes of Omo-Gibe river basin in Ethiopia. The Omo-Gibe Basin was delineated into 21 sub-basins and further divided into 270 Hydrological Response Units (HRUs) with 5\% LULC and 10\% soil class cover. The sensitivity analysis has identified 7 fundamental parameters (i.e., Cn2, ESCO, GWQMN, ALPHA_BF, Revapmn, Ch_K2, SOL_AWC) that control the surface and subsurface hydrological processes of the basin. However, CN2, ESCO and ALPHA_BF were found to be highly sensitive parameters than other parameters. The minimum temperature varies between 0.402 and $0.137{ }^{\circ} \mathrm{C}$ and $\%$ of 
Fig. 15 a Water balance in the basin and $\mathbf{b} \%$ change in mean annual water balance

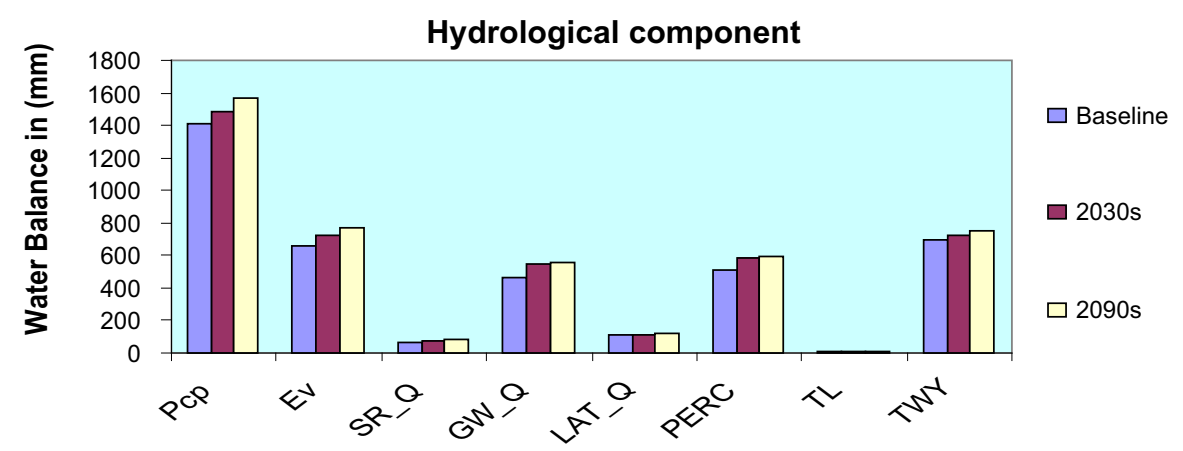

(a)

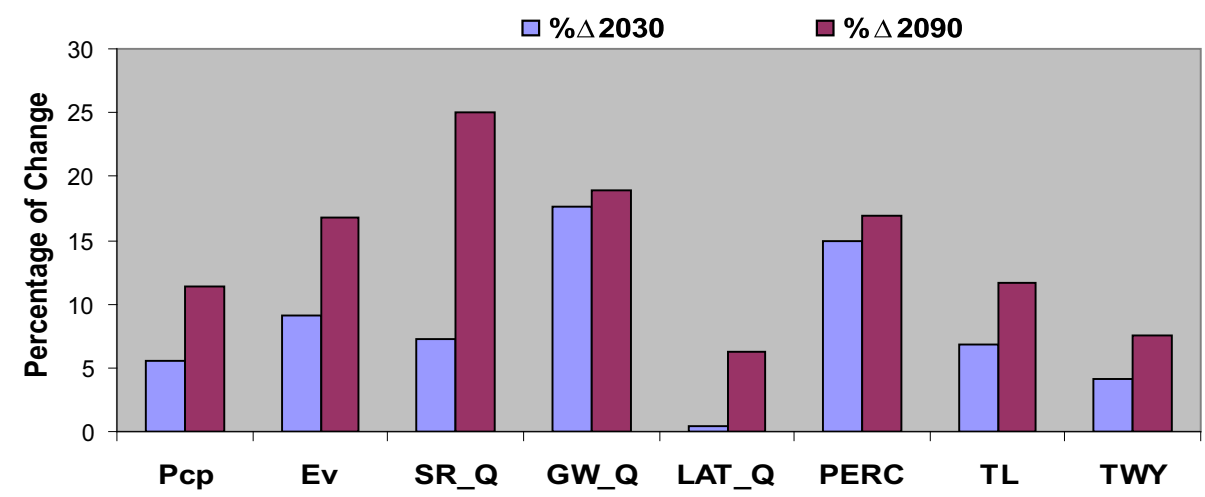

(b)

Table 9 Percentage of change precipitation and evaporation

\begin{tabular}{|c|c|c|c|c|}
\hline \multirow[t]{2}{*}{ Date } & \multicolumn{2}{|c|}{ Percentage of change in precipitation } & \multicolumn{2}{|c|}{ Percentage of change in evaporation } \\
\hline & $2030 \mathrm{~S} \Delta \%$ & $2090 \mathrm{~S} \Delta \%$ & $2030 \mathrm{~S} \Delta \%$ & $2090 \mathrm{~S} \Delta \%$ \\
\hline Jan & -22.0 & -39.3 & -10.98 & -11.84 \\
\hline Feb & 36.1 & -1.2 & 21.07 & 6.02 \\
\hline Mar & -12.3 & -2.2 & 7.81 & 15.76 \\
\hline Apr & -25.0 & -35.7 & -4.21 & -0.38 \\
\hline May & 3.7 & 15.5 & 5.33 & 9.93 \\
\hline Jun & 8.0 & 11.6 & 7.89 & 13.80 \\
\hline Jul & 6.0 & 12.7 & 7.77 & 20.35 \\
\hline Aug & -0.8 & 15.2 & 3.66 & 18.72 \\
\hline Sep & 4.4 & 3.2 & 8.05 & 20.73 \\
\hline Oct & 8.2 & 27.2 & 6.46 & 23.87 \\
\hline Nov & -27.4 & -19.9 & 10.49 & 4.12 \\
\hline Dec & -10.0 & 42.9 & 2.89 & 27.16 \\
\hline$\%$ mean annual change $(\Delta)$ & -2.58 & 2.49 & 5.52 & 12.35 \\
\hline
\end{tabular}

change at 2030 s found to be 1.57 and 0.50 at $2090 \mathrm{~s} \mathrm{A1B}$ scenario. The variation of the maximum temperature varies between 0.702 and $0.137{ }^{\circ} \mathrm{C}$ and $\%$ change at 2030s found to be 1.57 and $0.40{ }^{\circ} \mathrm{C}$ at 2090s in Upper Omo basin. The hydrological impact of the Omo-Gibe basin was analyzed with respect to three ten years period baseline
(1991-2000), near term (2031-2040), end term (2091-1000) A1B IPCC SRES climate change scenario. The percent of mean annual change of A1B scenario simulation on overall increasing pattern of precipitation and evaporation from -2.58 to 2.49 at $2030 \mathrm{~s}$ and 5.52 to 12.35 at 2090s, respectively. The results of Omo-Gibe 
Fig. 16 Percentage change of precipitation and evaporation
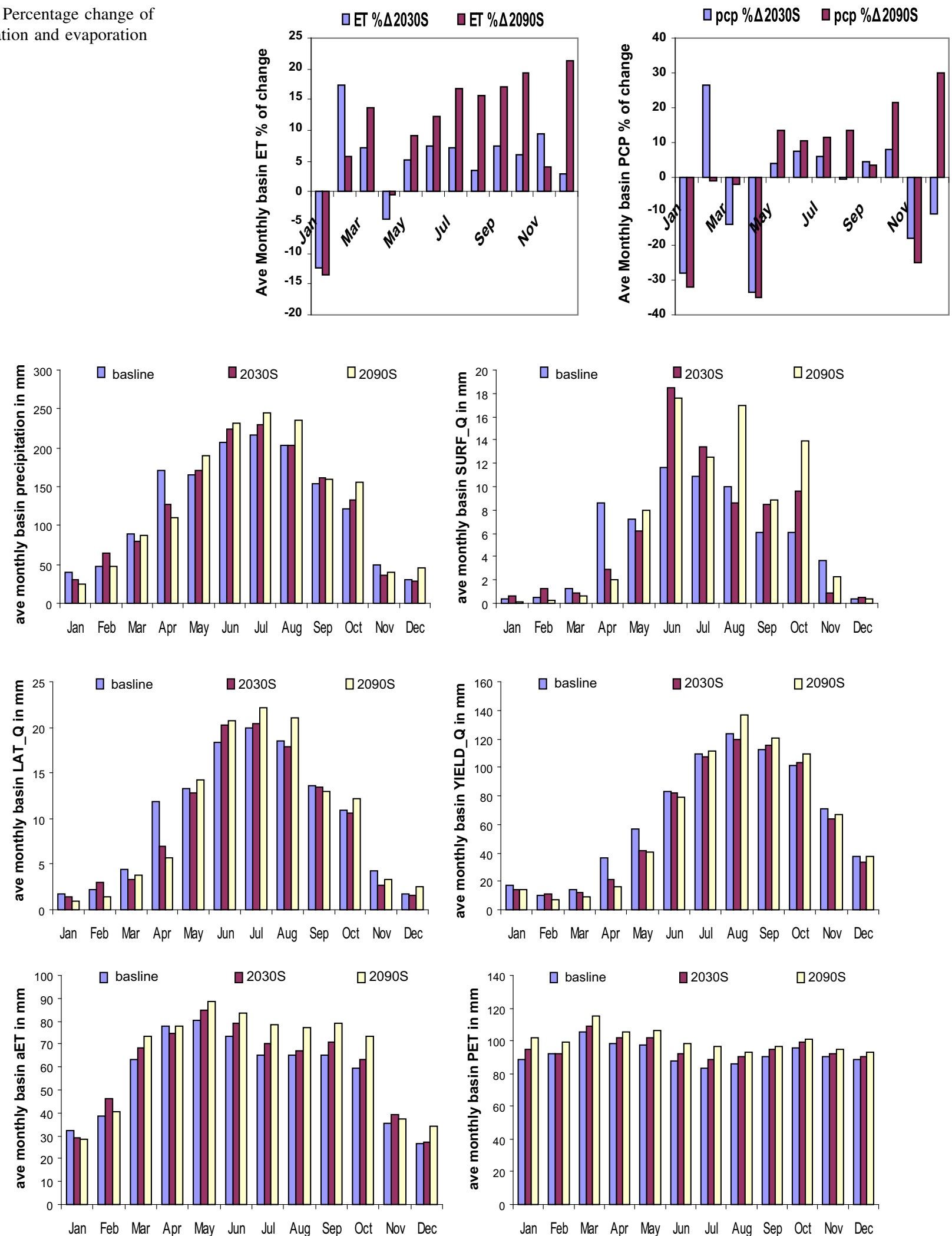

Fig. 17 The water balance on each hydrological component 
River basin study concluded that the SWAT model accurately tracked the measured flows and simulated well the monthly water yield. The study make the recommendation that SWAT model can be effectively used for assessing the water balance components of a river basin such as surface runoff, lateral flow, base flow and evapotranspiration. The simulated streamflow was found very close in agreement with measured streamflow. Finally this study gives support and increase awareness on the possible future impacts of climate change on basin water balance.

Acknowledgements The authors thankfully acknowledge Ministry of Water and Energy, National Meteorological Agency and Ministry of Agriculture, Ethiopia, for providing necessary data to this study.

\section{References}

Abbaspour KC, Van Genuchten MT, Schulin R, Schlappi E (1997) A sequential uncertainty domain inverse procedure for estimating subsurface flow and transport parameters. Water Resour Res 33(8):1879-1892

AfB UNEP, the World Bank (2003) Poverty and climate change: reducing the vulnerability of the poor through adaptation. In: Sperling F (ed) African Development Bank (AfDB). United Nations Environment Programme (UNEP) and the WB, Bonn, p 43

Allen RG, Pereira LS, Raes D, Smith M (1998) Crop evapotranspiration-guidelines for computing crop water requirements. FAO Irrigation and Drainage Paper No. 56, Rome

Arnold JG, Fohrer N (2005) SWAT-2000 current capabilities and research in applied watershed modeling. J Hydrol 19:53-572

Bosch DD, Sheridan JM, Batten HL, Arnold JG (2004) Evaluation of the SWAT model on a coastal plain agricultural watershed. Trans Am Soc Agric Eng (ASAE) 47(5):1493-1506

Chaulagain NP (2006) Impacts of climate change on water resources of Nepal: The physical and socioeconomic dimensions. M.Sc. thesis, University of Flensburg, Germany

Cotter AS, Chaubey I, Costello TA, Soerens TS, Nelson MA (2003) Water quality model output uncertainty as affected by spatial resolution of input data. $\mathrm{J}$ Am Water Resour Assoc 39(4):977-986

Dincer I, Midilli A, Hepbasli A, Karakoc TH (2009) Global warming: engineering solutions, Green Energy and Technology, Springer Science \& Business Media. ISBN 1441910174, 9781441910172

Ghosh S, Mujumdar PP (2009) Climate change impact assessment: uncertainty modeling with imprecise probability. J Geophys Res 114:D18113. doi:10.1029/2008JD011648
Intergovernmental Panel on Climate Change (IPCC) (2001) The scientific basis: regional climate information-evaluation and projections. http://www.ipcc.ch/ipccreports/tar/wg1/index.htm

IPCC (2001a) Climate Change (2001) Synthesis Report. In: Watson RT, Core Writing Team (eds.) Contribution of Working Groups I, II, and III to the Third Assessment Report of the IPCC. Cambridge University Press, Cambridge, p 398

IPCC (2001b) Climate Change (2001): impacts, adaptation, and vulnerability. In: McCarthy MC, Canziani OF, Leary NA, Dokken DJ, White KS (eds) Contribution of WG II to TAR of the Intergovernmental Panel on Climate Change. Cambridge, p 1031

IPCC (2007) Climate Change (2007): the physical science basis. In: Contribution of Working Group I to the Fourth Assessment Report of the Intergovernmental Panel on Climate Change. IPCC

Kim U, Kaluarachchi JJ, Smakhtin VU (2008) Climate change impacts on hydrology and water resources of the Upper Blue Nile River Basin, Ethiopia. International Water Management Institute Research Report, pp 126-127

Lenhart T, Eckhardt K, Fohrer N, Frede HG (2002) Comparison of two different approaches of sensitivity analysis. Phys Chem Earth 27:645-654

McSweeney C, New M, Lizcano G (2008) UNDP climate change country profiles Ethiopia. http://country-profiles.geog.ox.ac.uk

MoWR (Ministry of Water Resources) (1996) Integrated development of Omo-Gibe River Basin Master Plan Study, vol XI F1, F2, F3, Addis Ababa

Nash JE, Sutcliffe JE (1970) River flow forecasting through conceptual models - part 1-A: discussion of principles. J Hydrol 10(82):282-290

Neitsch SL, Arnold JG, Kiniry JR, Srinivasan R, Williams JR (2004) SWAT Input/output File Documentation, Version 2005

NMA (2007) National adaptation program of action of Ethiopia (NAPA). Final draft report. NMA, Addis Ababa

NMSA (2001) Initial National communication of Ethiopia to the United Nations Framework convention on climate change (UNFCCC). National Meteorological Services Agency, Addis Ababa

Sevruk B, Matokova-Sadlonova K, Toskano L (1998) Topography effects on small-scale precipitation variability in the Swiss preAlps. Hydrology, water resources and ecology in headwaters. In: Proceedings of the HeadWater'98 conference held at Meran/ Merano, Italy, April 1998. IAHS Publ. No. 248

Subramanya K (1998) Engineering hydrology, 2nd edn. Tata McGraw-Hill

Temesgen TD, Hassan RM, Ringler C (2006) Measuring Ethiopian farmers vulnerability to climate change across regional states, Washington DC

Yang J, Reichert P, Abbaspour KC, Xia J, Yang H (2008) Comparing uncertainty analysis techniques for a SWAT application to Chaohe Basin in China. J Hydrol 358:1-23 